\title{
LAPORAN KASUS \\ LIMFOMA MALIGNA PADA MATA \\ YANG DIRAWAT DI RUMAH SAKIT Dr. M. DJAMIL PADANG TAHUN 2003-2010
}

\author{
Linda Wira Putri, Ardizal Rahman \\ Bagian Mata Fakultas Kedokteran Universitas Andalas / \\ Rumah Sakit Dr. M. Djamil Padang, Sumatera Barat \\ E-mail : majalahkedokteranandalas@gmail.com
}

\begin{abstract}
Abstrak
Melaporkan kasus Limpoma pada Mata yang dirawat di RS. Dr. M. Djamil Padang.

Studi retrospektif dari 17 rekam medik yang didiagnosa sebagai limfoma pada mata di Bagian Mata RSUP dr. M. Djamil antara 2003 - 2010.

Terdapat 17 kasus limfoma pada mata di RSUP Dr. M. Djamil antara 2003 2010. Pasien laki-laki sebanyak 15 orang dan pasien perempuan 2 orang, dengan usia antara 4 bulan - 71 tahun. Keluhan utama paling sering $(82,35 \%)$ adalah proptosis pada mata. Semua pasien diperiksa dengan CT scan dan pemeriksaan histopatologis. Tipe limfositik yang paling banyak ditemukan secara histopatologis $(64,70 \%)$. Semua pasien dianjurkan untuk kemoterapi, tetapi hanya 10 pasien yang menjalani kemoterapi.

Proptosis pada mata merupakan tanda yang paling sering dari limfoma maligna pada pasien yang berobat di RSUP Dr. M. Djamil. Tipe limfositik adalah tipe yang paling sering. Tidak semua pasien menjalani kemoterapi karena adanya masalah ekonomi.
\end{abstract}

Kata kunci: Limfoma maligna, limfoma pada mata, proptosis

\footnotetext{
Abstract

Reporting cases of hospitalized ocular lymphoma at Dr. M. Djamil Hospital from 2003 - 2010.

Retrospective study of the medical records of 17 Ocular Lympomas diagnosed patients at the Ophthalmology Department of Dr. M. Djamil Hospital, between $2003-2010$.

There were 17 cases of Ocular Lymphoma at Dr. M. Djamil Hospital between 2003 - 2010. They are 15 male and 2 female patients, in range of age between 4 months to 71 years old. Most of them $(82.35 \%)$ have chief complaint proptosed of the eye since months to years. All patients were examined using CT imaging and histopatologically. Lymphosityc type was the most type of hystopathological characterictic (64.70\%) All patient were suggested to chemotherapy, but only 10 patients received chemotherapy.
} 
Proptosed of the eye was the most commont sign of malignant lymphoma patient visited at Dr. M. Djamil Hospital. Lymphosityc type was the most common type. Not all patients could receive chemotherapy for they have economic problems.

Key word: Malignant lymphoma,ocular lymphoma, proptosis 


\section{PENDAHULUAN}

Neoplasma limfoproliferatif menempati lebih dari $20 \%$ dari seluruh tumor orbita, dan tumor limfoid merupakan keganasan orbita primer terbanyak yang ditemui pada dewasa. Sebagian besar limfoma malignum orbita adalah tipe Non-Hodgkin yang muncul terutama pada kelompok umur $50-70$ tahun. ${ }^{(1,2)}$

Saat ini $70 \%-80 \%$ lesi limfoproliferatif orbita dianggap sebagai limfoma malignum berdasarkan marker permukaan sel monoklonal, sedangkan berdasarkan penelitian genetika ditemukan sebesar $90 \% .^{(3)}$

Adanya massa limfoid pada orbita dianggap abnormal karena pada jaringan lunak orbita yang normal, tidak terdapat limfosit dan kelenjar limfe. Limfoma pada orbita dapat berupa limfoma primer atau sekunder. Dikatakan limfoma primer bila orbita merupakan satu-satunya tempat terdapatnya limfoma ekstranodal, sedangkan pada limfoma orbita sekunder, limfoma timbul pada pasien yang sebelumnya sudah terdiagnosa sebagai limfoma Non-Hodgkin atau limfoma orbita yang muncul bersamaan dengan ditemukannya limfoma sistemik..$^{(1,4)}$

\section{GAMBARAN KLINIS}

Limfoma malignum orbita biasanya unilateral, namun dapat mengenai kedua mata dan menunjukkan predileksi pada kelenjar lakrimalis. Biasanya pasien datang dengan proptosis dengan onset yang perlahan-lahan, pergeseran bola mata ke bawah, edema palpebra, massa yang pada palpasi teraba padat dan tidak nyeri serta adanya ptosis. Pemeriksaan imaging menunjukkan adanya massa, tersering ditemukan pada bagian superior dan anterior orbita, juga dapat ditemui pada apeks orbita. ${ }^{(1,4-9)}$

Limfoma malignum tipe NonHodgkin ditemukan tiga kali lebih sering dibanding tipe Hodgkin. Keduanya dibedakan secara histopatologis, dimana pada limfoma Hodgkin ditemukan adanya sel ReedSternberg. ${ }^{(5,10)}$

Pada penyakit Hodgkin sering dijumpai adanya adenopati mediastinal anterior, demam, keringat malam, dan penurunan berat badan. Hal ini jarang dijumpai pada tipe Non-Hodgkin. ${ }^{(5,10)}$

Pada Limfoma Non-Hodgkin, $20 \%$ pasien mengalami splenomegali. Munculan awal berupa limfoma ekstranodal, dijumpai pada 1/3 kasus dan paling sering berupa limfoma histiositik difus, yang primernya terdapat pada traktus gastrointestinal. Pada 1/3 kasus lainnya juga ditemukan adanya invasi ke sumsum tulang. ${ }^{(5,11,12)}$

Pada awalnya sebagian besar pasien limfoma pada pemeriksaan darah perifer menunjukkan hasil yang normal, namun kemudian dalam perkembangannya akan dijumpai adanya anemia, infiltrasi sumsum tulang, perdarahan, dan hipersplenisme. Kadang-kadang terdapat limfositosis, terutama pada limfoma limfositik welldifferentiated. ${ }^{(5)}$

Secara klinis, limfoma Hodgkin dan Non-Hodgkin dapat dibedakan sebagai berikut : ${ }^{(10)}$ 


\begin{tabular}{|c|c|c|c|}
\hline \multirow[b]{2}{*}{ Karakteristik } & \multirow{2}{*}{$\begin{array}{l}\text { Limfoma } \\
\text { Hodgkin }\end{array}$} & \multicolumn{2}{|c|}{ Limfoma non Hodgkin } \\
\hline & & Low grade & $\begin{array}{l}\text { Intermediate/ } \\
\text { high grade }\end{array}$ \\
\hline Tempat asal & Nodal & $\begin{array}{l}\text { Ekstranodal } \\
(10 \%)\end{array}$ & $\begin{array}{c}\text { Ekstranodal } \\
(35 \%)\end{array}$ \\
\hline Distribusi nodal & $\begin{array}{l}\text { Sentripetal } \\
\text { (aksial) }\end{array}$ & Sentrifugal & Sentrifugal \\
\hline Penyebaran nodal & Sontiguous & Noncontiguous & Noncontiguous \\
\hline $\begin{array}{l}\text { Keterlibatan } \\
\text { susunan saraf pusat }\end{array}$ & $\begin{array}{l}\text { Jarang } \\
(<1 \%)\end{array}$ & $\begin{array}{l}\text { Jarang } \\
(<1 \%)\end{array}$ & $\begin{array}{l}\text { Jarang } \\
(<10 \%)\end{array}$ \\
\hline Keterlibatan hepar & Jarang & $\begin{array}{l}\text { Sering } \\
(>50 \%)\end{array}$ & Jarang \\
\hline $\begin{array}{l}\text { Keterlibatan } \\
\text { sumsum tulang }\end{array}$ & $\begin{array}{l}\text { Jarang } \\
(<10 \%)\end{array}$ & Sering $(>50 \%)$ & $\begin{array}{c}\text { Jarang } \\
(<20 \%)\end{array}$ \\
\hline $\begin{array}{l}\text { Keterlibatan } \\
\text { sumsum tulang } \\
\text { mempengaruhi } \\
\text { buruknya } \\
\text { prognosis }\end{array}$ & Ya & Tidak & $\mathrm{Ya}$ \\
\hline $\begin{array}{l}\text { Sembuh dengan } \\
\text { kemoterapi }\end{array}$ & $\mathrm{Ya}$ & Tidak & $\mathrm{Ya}$ \\
\hline
\end{tabular}

Perbandingan Klinis Limfoma Hodgkin dan Non-Hodgkin

\section{GAMBARAN MORFOLOGI}

Pemeriksaan histopatologi yang akurat merupakan langkah diagnostik yang penting dalam manajemen limfoma orbita. Seringkali perlu dilakukan open incisional biopsy atau aspirasi jarum halus pada massa orbita yang dicurigai sebagai suatu limfoma.

Diagnosis Limfoma Malignum ditegakkan bila ditemukan sel immatur yang difus serta limfosit yang aktif bermitosis. Pertanda histologi berupa sel B monoklonal dikonfirmasi dengan pemeriksaan immunohistokimia, dimana menunjukkan adanya nukleoli yang menonjol, marginasi kromatin ke membran nuklear, membran nuklear yang irreguler dan sel yang tidak beraturan. ${ }^{(1-6)}$

Sekitar 85 sampai 90\% limfoma orbita merupakan low grade, proliferasi difus, dan limfosit sel B monoklonal. Sisanya, $10-15 \%$ adalah noduler atau folikuler. ${ }^{(1,6)}$

\section{KLASIFIKASI}

Terdapat berbagai klasifikasi limfoma, diantaranya menurut 
Rappaport yang telah dimodifikasi pada tahun 1978, yang didasarkan pada sitologi dan histologi. Kemudian Working Formulation yang dibuat oleh National Cancer Institute pada tahun 1982, mengelompokkan limfoma berhubungan riwayat alami, respon pengobatan dan angka harapan hidup. Juga terdapat klasifikasi oleh LukesCollins pada tahun 1974 yang mengklasifikasikan limfoma secara histologi yang dikaitkan dengan adanya sel-B, sel-T, histiositik, dan sel U (undefined). ${ }^{(5)}$

\section{Perbandingan Klasifikasi Limfoma Non Hodgkin}

\begin{tabular}{|c|c|c|c|}
\hline $\begin{array}{c}\text { 5-year } \\
\text { survival }\end{array}$ & Working Formulation & $\begin{array}{l}\text { Klasifikasi } \\
\text { Rappaport }\end{array}$ & $\begin{array}{c}\text { Klasifikasi } \\
\text { Lukes-Collins }\end{array}$ \\
\hline \multirow[t]{4}{*}{$50 \%-70 \%$} & Low Grade & & \\
\hline & Small Limphocytic & $\begin{array}{l}\text { Limphocytic-well } \\
\text { differentiated. }\end{array}$ & $\begin{array}{l}\text { Small limphocyte } \\
\text { and plasmacytoid } \\
\text { limphocytoid }\end{array}$ \\
\hline & $\begin{array}{l}\text { Follicular, } \\
\begin{array}{l}\text { Predominantly } \\
\text { cleaved cell }\end{array}\end{array}$ & $\begin{array}{l}\text { Nodular, poorly } \\
\text { differentiated } \\
\text { limphocytic }\end{array}$ & FCC small cleaved \\
\hline & $\begin{array}{l}\text { Follicular, Mixed small } \\
\text { cleaved \&large cleaved } \\
\text { cell }\end{array}$ & $\begin{array}{l}\text { Nodular, mixed } \\
\text { limphocytic } \\
\text { histiocytic }\end{array}$ & $\begin{array}{l}\text { FCC small cleaved } \\
\text { and large cleaved }\end{array}$ \\
\hline \multirow[t]{5}{*}{$35 \%-40 \%$} & Intermediate Grade & & \\
\hline & $\begin{array}{l}\text { Follicular, predominantly } \\
\text { large cell }\end{array}$ & $\begin{array}{l}\text { Nodular, } \\
\text { histiocytic }\end{array}$ & $\begin{array}{l}\text { FCC, large cleaved, } \\
\text { and/or not cleaved }\end{array}$ \\
\hline & $\begin{array}{l}\text { Diffuse, small cleaved } \\
\text { cell }\end{array}$ & $\begin{array}{l}\text { Diffuse, poorly } \\
\text { differentiated } \\
\text { limphocytic }\end{array}$ & $\begin{array}{l}\text { FCC, small } \\
\text { cleaved, diffuse }\end{array}$ \\
\hline & $\begin{array}{l}\text { Diffuse, mixed large and } \\
\text { small cell }\end{array}$ & $\begin{array}{l}\text { Diffuse, mixed } \\
\text { limphocytic and } \\
\text { histiocytic }\end{array}$ & $\begin{array}{l}\text { FCC, small } \\
\text { cleaved, large } \\
\text { cleaved or large } \\
\text { noncleaved }\end{array}$ \\
\hline & Diffuse, large cell & $\begin{array}{l}\text { Diffuse } \\
\text { histiocytic }\end{array}$ & $\begin{array}{l}\text { FCC, large cleaved } \\
\text { or large noncleaved }\end{array}$ \\
\hline
\end{tabular}

\begin{tabular}{|c|c|c|c|}
\hline \multirow[t]{4}{*}{$23 \%-32 \%$} & High Grade & & \\
\hline & $\begin{array}{ll}\text { Large } & \text { cell, } \\
\text { immunoblastic } & \end{array}$ & Diffuse histiocytic & $\begin{array}{l}\text { Immunoblastic } \mathrm{B} \text { or } \\
\mathrm{T} \text { cell type }\end{array}$ \\
\hline & Limphobastic & $\begin{array}{l}\text { Limphoblastic } \\
\text { lymphoma }\end{array}$ & $\begin{array}{l}\text { Convoluted T cell } \\
\text { lymphoma }\end{array}$ \\
\hline & Small noncleaved cell & $\begin{array}{l}\text { Undifferentiated } \\
\text { Burkitt's and non } \\
\text { Burkitt's }\end{array}$ & $\begin{array}{l}\text { FCC small } \\
\text { noncleaved }\end{array}$ \\
\hline
\end{tabular}

FCC $=$ Follicular Center Cells

Di samping klasifikasi di atas, terdapat klasifikasi menurut The Revised European-American Classification of Lymphoid Neoplasms (REAL). 
Klasifikasi Limfoma Non-Hodgkin menurut REAL

\section{Indolenf Lymphomas}

Follicular lymphoma

B-chronic lymphocytic leukemia/small lymphocytic lymphoma

Lymphoplasmacytic lymphoma

Marginal zone lymphoma ¡nodal, extranodal, splenic!

T-cell/natural killer large cell granular lymphocyte leukemia

T-chronic lymphocytic leukemia/ prolymphocytic leukemia

\section{Aggressive Lymphomas}

Mantle cell lymphoma

Diffuse large B-cell lymphoma

Peripheral T-cell lymphoma iunspecified!

Peripheral T-cell lymphoma [angioimmunoblastic, angiocentric!

T-cell/natural killer cell, hepatosplenic, intestinal T-cell lymphoma

Anaplastic large cell lymphoma

\section{Highly Aggressive Lymphomas}

Precursor T or B lymphoblastic leukemia/ lymphoma

Burkitt's and Burkitt's-like lymphoma Adult T-cell leukemia/lymphoma

Harris NL, 1994. Dikutip dari Esmaeli (2005)

Klasifikasi tersebut diatas digunakan untuk limfoma tipe Non-Hodgkin, sedangkan untuk menentukan stadium baik tipe Hodgkin maupun NonHodgkin, dapat digunakan klasifikasi Ann Arbor. 
Stadium Limfoma berdasarkan kesepakatan Ann Arbor

\begin{tabular}{|c|c|}
\hline Stadium & Keterangan \\
\hline I & $\begin{array}{l}\text { Pembesaran kelenjar getah bening (KGB) hanya } 1 \text { regio } \\
\text { I E: jika hanya terkena } 1 \text { organ ekstra limfatik tidak difus / } \\
\text { batas tegas }\end{array}$ \\
\hline II & $\begin{array}{l}\text { Pembesaran } 2 \text { regio } \mathrm{KGB} \text { atau lebih, tetapi masih satu sisi } \\
\text { diafragma } \\
\text { II 2: pembesaran } 2 \text { regio } \mathrm{KGB} \text { dalam } 1 \text { sisi diafragma } \\
\text { II 3: pembesaran } 3 \text { regio } \mathrm{KGB} \text { dalam } 1 \text { sisi diafragma } \\
\text { II E: pembesaran } 1 \text { regio atau lebih } \mathrm{KGB} \text { dalam } 1 \text { sisi } \\
\text { diafragma dan } 1 \text { organ ekstra limfatik tidak difus / batas tegas }\end{array}$ \\
\hline III & Pembesaran KGB di 2 sisi diafragma \\
\hline IV & $\begin{array}{l}\text { Jika mengenai } 1 \text { organ ekstra limfatik atau lebih tetapi secara } \\
\text { difus }\end{array}$ \\
\hline
\end{tabular}

\section{DIAGNOSIS}

Diagnosis Limfoma pada orbita ditegakkan melalui work up yang direkomendasikan sebagai berikut : ${ }^{(1)}$

- Anamnesa dan pemeriksaan fisik

- Pemeriksaan oftalmologi

- Pemeriksaan darah lengkap dan biokimia darah

- Tes fungsi hati

- Rontgen thoraks

- CT atau MRI orbita

- CT abdomen, thoraks dan pelvis

- Aspirasi sumsum tulang

- Open or fine needle biopsy dari massa orbita.

- Endoskopi dan pemeriksaan barium

- Pemeriksaan total body positron emission tomography (PET)

\section{PENATALAKSANAAN}

- Radioterapi : Limfoma bersifat radiosensitive. Dosis radiasi yang biasa diberikan rata-rata $40 \mathrm{~Gy}$.
- Kemoterapi : Dapat diberikan obat kemoterapi tunggal maupun kombinasi.

- Immunoterapi : dengan pemberian antibodi monoklonal

- Radioimmunoterapi : gabungan immunoterapi dengan terapi menggunakan radioaktif

- Kombinasi.

\section{HASIL PENELITIAN}

Selama tahun $2003-2010$ terdapat 17 kasus limfoma malignum yang dirawat di Bagian Mata RS Dr. M. Djamil Padang.

\section{Distribusi menurut jenis kelamin}

\begin{tabular}{lll}
\hline $\begin{array}{l}\text { Jenis } \\
\text { Kelamin }\end{array}$ & Jumlah & $\%$ \\
\hline Pria & 15 & 88,24 \\
Wanita & 2 & 11,76 \\
\hline Total & 17 & 100 \\
\hline
\end{tabular}

Tabel di atas menunjukkan Limfoma Malignum ditemui lebih banyak pada pria $(88,24 \%)$ dibanding wanita $(11,76 \%)$ 


\section{Distribusi menurut umur}

\begin{tabular}{lll}
\hline $\begin{array}{l}\text { Umur } \\
\text { (tahun) }\end{array}$ & Jumlah & $\%$ \\
\hline$\leq 20$ & 3 & 17,64 \\
$21-40$ & 1 & 5,88 \\
$41-60$ & 11 & 64,70 \\
$\geq 61$ & 2 & 11,76 \\
\hline Total & 117 & 100 \\
\hline
\end{tabular}

Sebagian besar pasien Limfoma Malignum berumur antara $41-60$ tahun $64,70 \%$ )

\section{Distribusi menurut gejala klinis}

\begin{tabular}{lll}
\hline $\begin{array}{l}\text { Gejala } \\
\text { Klinis }\end{array}$ & Jumlah & $\%$ \\
\hline Proptosis & 14 & 82,35 \\
Bukan & 3 & 7,65 \\
proptosis & & \\
\hline Total & 17 & 100 \\
\hline
\end{tabular}

Kebanyakan pasien datang dengan keluhan proptosis $(82,35 \%)$.

\section{Distribusi menurut pemeriksaan histopatologi}

\begin{tabular}{|c|c|c|}
\hline $\begin{array}{l}\text { Kategori } \\
\text { histopatologi }\end{array}$ & Jumlah & $\%$ \\
\hline $\begin{array}{l}\text { - Lymphocytic } \\
\text { type } \\
\text { - Diffuse,mixed } \\
\text { small \& large } \\
\text { cell } \\
\text { - Diffuse,large } \\
\text { cell }\end{array}$ & $\begin{array}{l}11 \\
4 \\
2\end{array}$ & $\begin{array}{l}64,70 \\
23,53 \\
11,77\end{array}$ \\
\hline Total & 17 & 100 \\
\hline
\end{tabular}

Semua pasien dilakukan biopsi untuk pemeriksaan histopatologi. Sebagian besar pasien menunjukkan gambaran histopatologi Lymphocytic type

\section{Distribusi menurut manajemen terapi}

\begin{tabular}{lll}
\hline $\begin{array}{l}\text { Manajemen } \\
\text { Terapi }\end{array}$ & $\begin{array}{l}\text { Ju } \\
\text { mla } \\
\text { h }\end{array}$ & \\
\hline Kemoterapi & 10 & 58,82 \\
Radiasi & - & - \\
Terapi monoklonal & - & - \\
antibodi & 7 & 41,18 \\
Menolak & & \\
Kemoterapi & & \\
\hline & 17 & 100 \\
\hline
\end{tabular}

Hanya $58,82 \%$ pasien yang dilakukan kemoterapi, sisanya menolak kemoterapi, sebagian besar karena alasan ekonomi.

\section{DISKUSI}

Limfoma malignum merupakan transformasi neoplastik dari sel yang terdapat pada jaringan limfoid, yang meliputi limfosit, histiosit dan precursor serta derivatnya. Sering terdapat pada kelenjar limfe, namun dapat ditemui pada ekstranodal misalnya kulit, sumsum tulang, orofaring dan mata. ${ }^{(1-6,13)}$

Dari semua pasien pada penelitian ini, aspirasi sumsum tulang dilakukan pada 1 pasien, yaitu seorang pasien berumur 4 bulan atas konsultasi dengan bagian anak. Sedangkan pemeriksaan CT scan orbita dilakukan pada semua pasien, dimana menunjukkan adanya massa orbita, yang memberi kesan suatu limfoma.

Pada penelitian ini didapat lebih banyak pria $(88,24 \%)$ dibanding wanita. Sedangkan Esmaeli (2005) menyatakan rasio pria : wanita adalah 1:1. Sebagian besar pasien Limfoma 
Malignum pada penelitian ini berkisar pada umur 41 - 60 tahun $(64,70 \%)$, hal ini hampir sama dengan literatur yang menyatakan bahwa pada dewasa terutama ditemui pada usia $50-70$ tahun. $^{(1)}$

Dari semua kasus Limfoma Malignum yang ditemukan di RS dr. M. Djamil Padang pada tahun 2003 2010, 82,35\% mempunyai keluhan proptosis. Sebrina dan Rahman pada penelitian di RS Dr. M. Djamil Padang tahun 2005 mendapatkan bahwa Limfoma Malignum merupakan penyebab terbanyak terjadinya proptosis bulbi yaitu $16,67 \% .^{(14)}$

Berdasarkan

kategori

histopatologi, pasien Limfoma Malignum pada penelitian ini dikelompokkan sebagai berikut : ${ }^{(5)}$

- Lymphocytic type

- Diffuse,mixed small \& large cell

- Diffuse,large cell

Semua pasien pada penelitian ini dilakukan pemeriksaan histopatologi. Yang ditemukan paling banyak pada penelitian ini adalah tipe limfositik (well differentiated) yaitu $80 \%$. Di literatur dinyatakan bahwa sebagian besar kasus limfoma orbita adalah tipe proliferatif difus, dan dari semua tipe proliferatif difus separuhnya adalah tipe limfositik well differentiated atau mixed limfositik dan histiositik. ${ }^{(1,4-6)}$

Terapi yang direkomendasikan pada pasien dengan low grade orbital lymphoma adalah dengan radioterapi, sedangkan pada pasien dengan subtipe histologis yang lebih agresif dengan keterlibatan sistemik lebih baik dilakukan kemoterapi dan immunoterapi sistemik. Pada sejumlah pasien dimungkinkan untuk terapi kombinasi kemoterapi lokal dengan radioterapi lokal, biasanya pada pasien dengan limfoma intermediate dan high grade.
Pemilihan pendekatan terapi pada tiap pasien berbeda-beda berdasarkan

stadium dan klasifikasi limfoma secara histologis, dengan mempertimbangan faktor resiko komorbid. ${ }^{(2,15-18)}$

Limfoma pada umumnya bersifat radiosensitif. Pada stadium I limfoma orbita indolent, dapat dicapai kontrol lokal pada lebih dari 90\%, namun kejadian distant relapse nya masih $40 \%$ bila hanya diterapi dengan radioterapi saja. Kemoterapi yang dikombinasi dengan radioterapi menunjukkan 5-year rates of relapsefree survival pada 94 - $100 \%$ pada stadium I, dan $72-78 \%$ pada stadium II. $^{(2,19)}$

Pada penelitian ini, semua pasien dianjurkan untuk kemoterapi, namun hanya 10 pasien yang menjalaninya. Sisanya menolak untuk dilakukan kemoterapi, sebagian besar dengan alasan ekonomi.

Kemoterapi

biasanya

diindikasikan untuk limfoma orbita dengan subtipe histologis yang lebih agresif yang potensial untuk terjadinya penyebaran secara sistemik atau disseminata. Limfoma indolent sangat sensitif terhadap kemoterapi tunggal maupun kombinasi. Kemoterapi tunggal dilakukan dengan pemberian alkylating agent, seperti siklofosfamid. Pada limfoma intermediate dan highgrade, biasanya diberikan kemoterapi kombinasi, berupa siklofosfamid, doksorubisin, vinkristin, dan prednison (CHOP) atau siklofosfamid, vinkristin, doksorubisin, dan deksametason (CVAD). ${ }^{(1,11,12)}$

Meskipun radioterapi cukup efektif dalam mengontrol limfoma, namun masih dimungkinkan terdapat relaps dan terjadinya toksik okuler. Demikian pula dengan kemoterapi, walau cukup efektif pada stadium yang lebih tinggi, namun pemberian kemoterapi yang agresif pada pasien 
usia tua menimbulkan masalah dengan adanya penyakit komorbid. Oleh karena itu, saat ini dikembangkan terapi alternatif berupa immunoterapi. ${ }^{(1)}$

Terapi antibodi monoklonal cukup efektif untuk limfoma NonHodgkin low-grade. Pada tahun 1997 diperkenalkan antibodi monoklonal pertama yang digunakan untuk terapi kanker, sekaligus merupakan obat pertama yang secara spesifik ditujukan untuk terapi limfoma, yaitu Rituximab. Rituximab diberikan berupa infus intravena dengan dosis $375 \mathrm{mg} / \mathrm{m} 2$ sekali seminggu, selama 4 minggu berturut-turut. ${ }^{(1)}$

Saat ini juga dikembangkan radioimmunoterapi, yaitu pemberian antibodi monoklonal yang dikombinasi dengan radioaktif (Zevalin). Zevalin yang dikombinasi dengan Rituximab menunjukkan efikasi yang lebih baik untuk terapi limfoma low-grade, dibanding bila terapi dengan Rituximab saja. ${ }^{(1)}$

\section{KESIMPULAN}

Selama tahun 2003 sampai 2010 terdapat 17 kasus Limfoma Malignum orbita di Rumah Sakit dr. M. Djamil Padang, terdiri dari 15 pria dan 2 wanita, dengan rentang usia mulai dari usia 4 bulan sampai dengan 71 tahun. Sebagian besar penderita $(82,35 \%)$ datang dengan proptosis yang telah berlangsung bulanan sampai tahunan. Semua penderita dilakukan CT Scan dan pemeriksaan histopatologi, yang selanjutnya diberikan kemoterapi. Sebanyak 58.82\% pasien menjalani kemoterapi, sedangkan sisanya menolak kemoterapi.

\section{KEPUSTAKAAN}

1. Esmaeli B, Faustina M. Orbital Lymphoma. In: Karcioglu ZA, editor. Orbital Tumors, Diagnosis and Treatment. New York: Springer; 2005. p. 133 40.

2. Skuta GL, Cantor LB, Weiss JS. Basic and Clinical Science Course, Ophthalmic Pathology and Intraocular Tumors. San Francisco: American Academy of Ophthalmology; 2008.

3. Liesegang TJ, Skuta GL, Cantor LB. Basic and Clinical Science Course, Orbit, Eyelids, and Lacrimal System. San Francisco: American Academy of Ophthalmology; 2008.

4. Specht CS. Benign and malignant lymphoid tumors, leukemia, and histiocytic lesions. In: Albert DM, Jakobiec FA, editors. Clinical Practice, Principles and Practice of Ophthalmology, Volume 5. Philadelphia: W.B. Saunders Company; 1994.p..3328-45.

5. Jacobiec FA, Jones IS. Lymphomatous, Plasmacytic, Histiocytic and Hematopoeitic Tumor. In: Tasman W, editor. Duane's Foundation of Clinical Ophthalmology. Philadelphia: JB Lippincott Company; 1993; 39: 1-19.

6. Rootman J, White VA, Connors $\mathrm{JM}$ et al. Lymphoproliferative, leukemic, and histiocytic lesions of the orbit. In: Rootman J, editor. Diseases of 
the orbit, A Multidisciplinary Approach, $\quad 2^{\text {nd }} \quad$ edition. Philadelphia: $\quad$ Lippincott Williams \& Wilkin; 2003. 385 -416 .

7. Garrity JA, Henderson JW, Cameron JD. Henderson's Orbital Tumors, Fourth Edition. Philadelphia: Lippincott Williams \& Wilkins; 2007.

8. Grimm SA, Pulido JS, Jahnke $\mathrm{K}$ et al. Primary Intraocular Lymphoma: an International Primary Central Nervous System Lymphoma Collaborative Group Report. J Annals of Oncology 2007; 1-5.

9. Nutting $\mathrm{CM}$, Jenkins $\mathrm{CD}$, Norton AJ. Primary Orbital Lymphoma. The Hematology Journal. 2002; 3: 14 - 16 .

10. Sumantri R. Penyakit Hodgkin. Dalam : Buku Ajar Ilmu Penyakit Dalam Jilid II. FKUI, 2006 : 735-7.

11. Reksodiputro AH, Irawan C. Limfoma Non-Hodgkin (LNH). Dalam : Buku Ajar Ilmu Penyakit Dalam Jilid II. FKUI, 2006: 728-34.

12. Freedman AS, Nadler LM. Limfoma Maligna. Dalam: Harrison, Prinsip-prinsip Ilmu Penyakit Dalam.Terj. Asdie AH. Jakarta: EGC. 2000: 197388.
13. Reese AB. Tumors of the Eye, Third Edition. New York: Medical Department Harper \& Row, Publisher. 1992.

14. Sebrina ES, Rahman A. Etiologi Protusio Bulbi. PIT PERDAMI ke-31 Batam, Juni 2005.

15. Esmaeli B, Murray JL, Ahmadi MA et al. Immunotherapy for Low Grade Non-Hodgkin Secondary Lymphoma of the Orbit. Arch Ophthalmol. 2002; 120: $1225-27$.

16. Yadav BS, Sharma SC. Orbital Lymphoma: Role of Radiation. Indian Journal of Ophthalmology. 2009; 57: $91-$ 97.

17. Lau HY, Chua ET, Yang TL. Orbital Lymphoma: Result of Radiation Therapy. Annals Academy of Medicine.1998; $27: 474-7$.

18. Bennett CL, Putterman A, Bitran JD et al. Staging and Therapy of Orbital Lymphomas. Cancer. 1986; 57: $1204-08$.

19. Bischof M, Zierhut D, Neuhof $D$ et al. Indolent Stage IE NonHodgkin's Lymphoma of the Orbit: Result after Primary radiotherapy. Ophthalmologica. 2007; 221: 348 - 52. 